\title{
Ancient Topography of the Mid Calore Valley: the City of Aeclanum and its Territory
}

\author{
Immacolata Ditaranto \\ Laboratory of Ancient Topography, Archaeology and Photogrammetry (LabTAF), University of Salento, \\ Lecce, Italy \\ email: immadit@libero.it
}

\section{Abstract}

The study area is located in the mid Calore valley, between the Calore and the Ufita Rivers. From prehistoric times, the territory has constituted an important crossroad among Campania, Apulia and Lucania, ensuring a connection between the Tyrrenian and Adriatic coast. The importance of the area grew with the construction of the via Appia, in the third century BC. Along its route, as documented by itinerary sources, in the early first century BC the municipium of Aeclanum (Passo di Mirabella Mirabella Eclano, AV) was founded. A significant part of the research project regards this city: archaeological field surveys were carried out in the urban area and along the city walls, still partially preserved, with the aim to clarify its route. The new collected data were georeferenced in an aerophotogrammetric map, together with the data deriving from 1960s archaeological excavations and systematic study of archival documents of the Superintendence of Salerno, Avellino, Benevento and Caserta Province. The map was realised in the LabTAF of the University of Salento and constitutes the first large scale archaeological map of the ancient city. Systematic archaeological field walking was carried out on the territory corresponding partially to the ager Aeclanensis. It aimed at the reconstruction of the ancient topography of the territory surrounding the Roman site thanks to the large number of settlements documented. These settlements attest to the inhabitation of the area since the prehistoric and proto-historic times to the Medieval period. All collected data are georeferenced in the archaeological map that also allows diachronic analyses of the territory.
Keywords: Ancient Topography; Aerial Archaeology; Archaeological Map; Photogrammetry; Field Survey.

\section{The Archaeological Map of the City: Methodology and Results}

Most frequently the lack of suitable cartography for archaeological research on the ground determines the need to create cartographic bases from scratch. All the more true and necessary when the research is related to ancient cities where the amount of remains on the surface is usually such to require a base-map characterised by a good detail in scale and themes. The new aerophotogrammetric map of Aeclanum (Passo di Mirabella, Mirabella Eclano, AV) was created, in the first place, to fill in for the lack of updated cartography. The map was done in a large-scale $(1: 2,000)$ and suitable for the positioning of archaeological features discovered during the activities of protection carried out over the last 80 years (such as the systematic excavations in the urban area and necropolises) by the Soprintendenza per i Beni Archeologici di Salerno, Avellino, Benevento e Caserta. Second, the map constitutes an indispensable tool during archaeological field walking for the correct positioning of new evidence surveyed along the city walls, in the urban and suburban area (Ditaranto 2013). The ultimate goal of the research was to allow an overall understanding of the data, overcoming the fragmentation of the knowledge by integrating all data collected (fig. 1). Also integrated into the map were all traces identified in the rich data-set of aerial photographs available, starting from the historic ones of $1950 \mathrm{~s}$ 


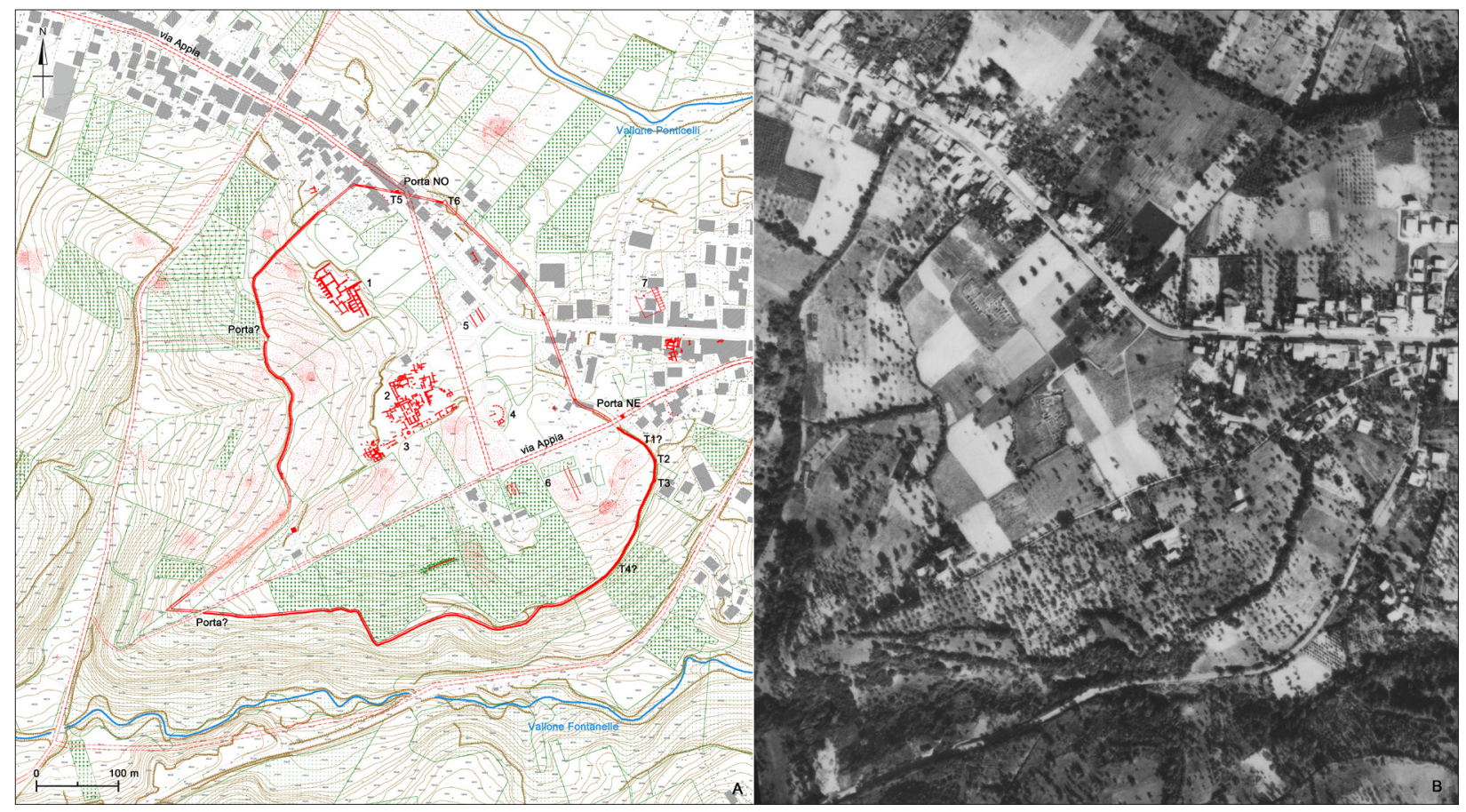

Fig. 1. A, Detail of archaeological map of Aeclanum: 1, baths; 2 , residential quarter; 3 , Paleochristian basilica; 4, macellum; 5, "fountain"; 6, "area of Theatres"; 7 , Sanctuary of Mephitis. B, Aeclanum in an historical aerial photographs (ESACTA 1974, phot. 1736, strip 7).

to the oblique images collected during low flies in the last years.

The urban area of Aeclanum covers approximately 22 ha on a plateau with a characteristic triangular shape with the tip pointing south-west, defined by walls in opus incertum, only partially preserved, erected after the establishment of the municipium (CIL IX 1140; Sgobbo, 1931: 6-8) which took place after the conquest by Silla (App. 1.51). The city is mentioned in literary sources and itineraria from Late Republican times with some little variations that mark the progressive change from an Archaic diction, Aeculanum, to the consolidated one of Aeclanum (Colonna, 1960: 207-208; Hulsen, 1894: 443-44). In the Republican period the city assumes considerable importance within the communication network between Campania and Apulia, being crossed by the via Appia, which was renewed in the mid Imperial Age ICIL IX
$6072,6074,6075)$ when the via Herdonitana also was paved (CIL IX 1156, 1175, 1414). The last one directly connected Aeclanum, probably the caput viae, to Herdonia.

The knowledge of the urban area and city walls, after the nineteenth century studies (Guarini 1812; Ruggiero, 1888: 480-83) and those conducted during the first decades of the twentieth century (Sgobbo, 1930: 400-11; 1931) results from the archaeological excavations carried out in the second half of the 1950s of the twentieth century IOnorato 1960). Until now, several excavations of the Soprintendenza per i Beni Archeologici di Salerno, Avellino, Benevento e Caserta continue to involve the main monuments of the Roman and Late Antique city (Lo Pilato, 2010 with previous bibliography; Nava, 2011: 748-49).

Archaeological field surveys, together with the analysis of a rich data-set of aerial photographs, have allowed the addition of new data on the city walls, about two kilometres long and only partially preserved on the western side. Nevertheless, it is easily seen in the air photographs due to the orography and the peculiar shape of the plateau on which the city lies. These data were well integrated with those coming from archival documents 


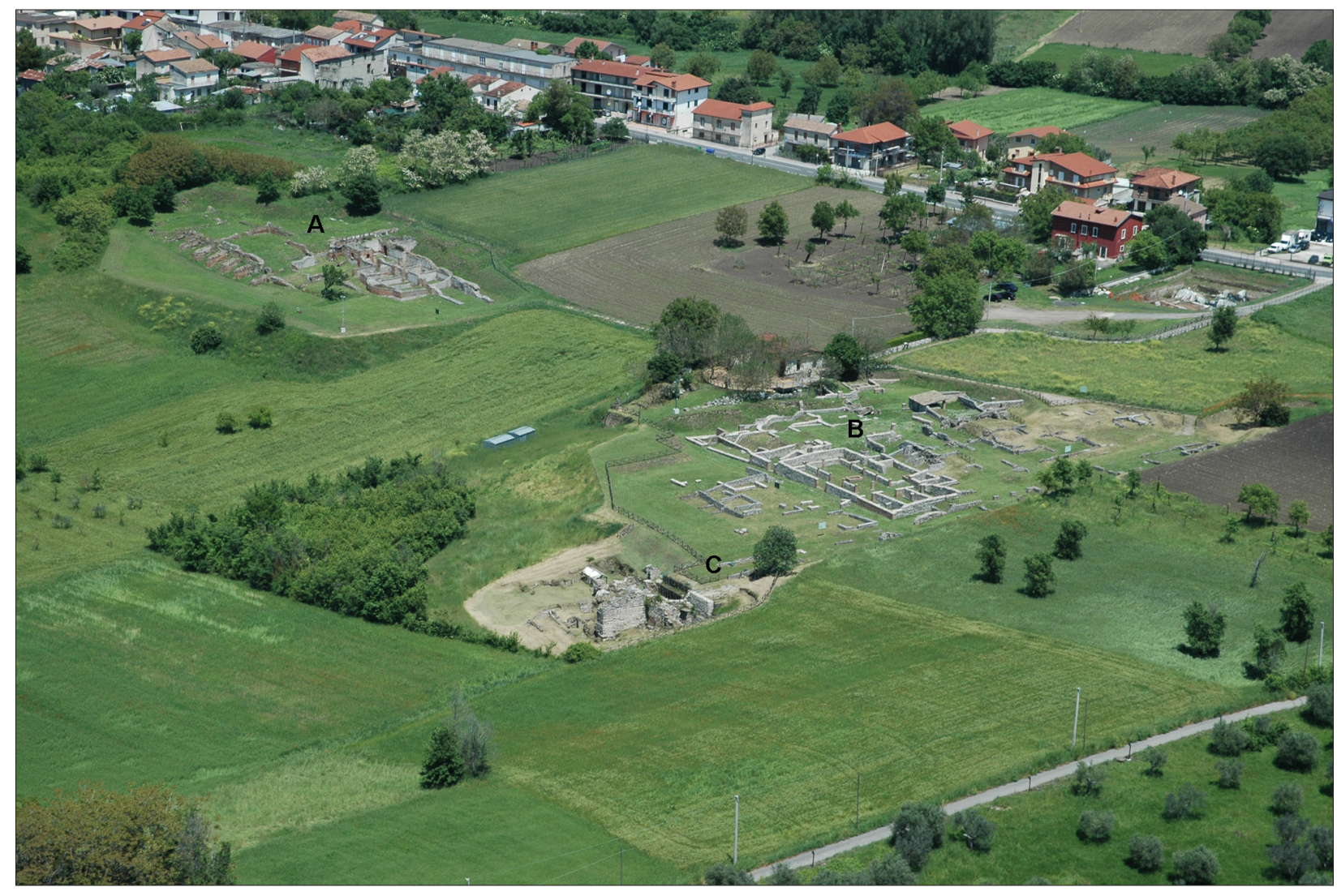

Fig. 2. View of archaeological remains at Aeclanum from south-east, taken during a low fly on May 2010: A, baths; $B$, residential quarter; $C$, Paleochristian basilica.

of the Soprintendenza per i Beni Archeologici di Salerno, Avellino, Benevento e Caserta, describing some stretches of fortifications and two towers on the western side of the perimeter.

Some issues remain open and will only be answered with new excavation campaigns. Among these issues, the most important are the layout of the urban area, the correct location of the forum, and the area of the theatre and amphitheatre. The aerial photographs show the absence of a constant orientation of the visible structures and the presence, on the contrary, of individual areas of the city oriented in dependence of orography. In the residential district, archaeological excavations have identified a block determined by four roads, of which two basolate, which seem to be characterised by a side of m 50 circa (Di Giovanni, 1996: 242). The paved road that borders the block to the west is the only one that is non-orthogonal as compared to the others, assuming an orientation slightly divergent with respect to the internal walls and giving the block a trapezoidal shape. This anomaly is easily interpreted as a ruse adopted to overcome the extreme irregularity that characterises the morphology of ground surface at this point, or as a change of orientation in a phase of urban renewal.

Furthermore, it is conceivable that the monumental buildings of the Roman Imperial period that are visible were conditioned in their orientation, at the time of construction, from pre-existing structures, such as those recently discovered and dated between the third and second centuries BC /Colucci Pescatori, 1991: 99; Di Giovanni, 1996: 241, 250). Moreover, the orientation of the block is slightly rotated to the north compared to the thermal baths, located on the hill occupied by the western sector of the city, from which the residential district is divided by a cleft (fig. 2). This orientation may have been influenced by the direction of the via Appia in 


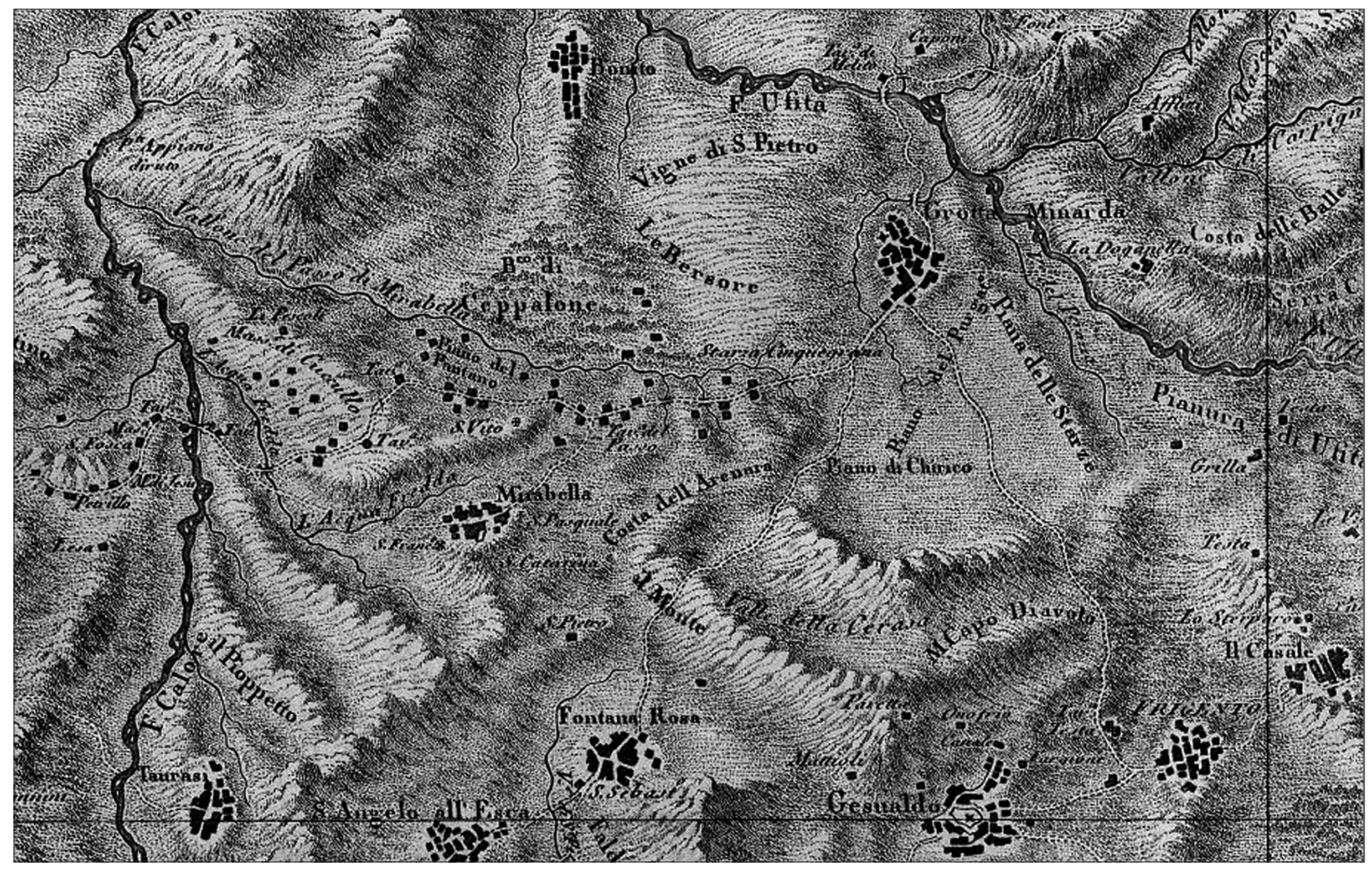

Fig. 3 here: Fig. 3. The territory of Aeclanum in a detail of Map 15 of Atlante Geografico del Regno di Napoli by Rizzi Zannoni (1808).

this sector of the urban area, as at Herdonia, where buildings, including the basilica and baths, follow the route of via Traiana, modifying also the size and shape of the blocks (Mertens, 1971: 11).

\section{Exploring and Reconstructing the Ancient Landscape of Aeclanum}

The central role that the city plays from the Late Republican period, with the creation of a municipium along the via Appia and afterwards with the increase of Colonia, undoubtedly invests the dynamics of population in the territory. The boundaries of the territory relating to the colony are unknown but they probably extended beyond the Ufita River, to the east, while to the west, the Calore River may have actually been the boundary with the agri of Beneventum and Abellinum.

Most part of the territory was investigated by direct and systematic field survey using large and medium-scale cartography 1:5,000 and 1:25,000). The investigated area, which covers approximately $74 \mathrm{~km}^{2}$ from the Calore to the Ufita Rivers, had been focused on in the past only by sporadic field surveys. The aim was to achieve an integral knowledge of the considerable material and settlements present in the territory and to allow a historic reconstruction from pre-historic times to the Medieval period. In addition, all the collections preserved in the Archaeological Museum Irpino in Avellino and in the Civic Museum in Mirabella Eclano were studied, as also the two largest private collections housed in Bonito (AV). Moreover, using this perspective, the site of provenance of the archaeological evidence found in the territory of Grottaminarda and unpublished, preserved in the Antiquarium at Grottaminarda (AV) has been carefully positioned on the map. Finally, the archaeological map of the area converged data already in the SIT of LabTAF and released in 2006/2007 by the Soprintendenza per i Beni 
Archeologici di Salerno, Avellino, Benevento e Caserta. Furthermore, archaeological survey allowed detailed analysis of the issue of via Appia's route in the territory of Aeclanum labout this question see Lo Pilato, 2013) and of the secondary road network, as well as the question of existence of an ancient regular land division. The landscape is characterised by rugged orography that softens particularly near the river valleys.

The presence of numerous small waterways and ditches mark the territory and make it particularly flourishing and fertile. The same fecundity must have also characterised the territory in ancient times, when the forest had to have covered a greater part than now, as seen by the numerous toponym with "Bosco" surviving in the cartography of the nineteenth and twentieth century (fig. 3).

Therefore, the territory was particularly suitable to be inhabited since ancient times; in fact, evidence of all phases of the Neolithic have been documented mainly in many areas west of the Ufita and east of the Calore Rivers. The Eneolithic epoch is strongly represented in the territory, with cases of sites that register continuity of life already present during the Late Neolithic; this evidence will be posed next to the already known site of Madonna delle Grazie (Mirabella Eclano), where a necropolis has been investigated (Onorato, 1960: 29-31).

Characterised by the facies of Palma Campania, along the right bank of the Calore River, a settlement marks the transition from the Eneolithic to the Bronze Age (Talamo \& Ruggini, 2005). In the investigated area, the Bronze Age is documented in many contexts and, as for the earlier period, the privileged spaces are situated near rivers, ditches and streams. This phase is also documented by Apennine and Late Bronze pottery found in an area, partially frequented in prehistoric times. Here, the remains of large food containers confirm that the economy of these settlements was based also on agricultural practice (Galasso, 2001: 4). In the investigated area, the archaeological record related to the Archaic period (sixth-fifth centuries $\mathrm{BC}$ ) is poor; the timelines identified are always present in contexts with continuity from protohistoric to late Roman time and consist mainly of fragments of globular jars or pithoi. The presence of items from the pre-Roman period, attributable to Samnite people and dating from the fourth century BC, is only sporadically documented.

Between the third and second centuries BC, the surroundings of Aeclanum register the presence of rustic settlements, referable to farms. A higher density of settlements, sometimes documented by small areas of necropolises dating back to the turn of the mid and the late Republican Age, have been detected in the territory placed north of the ancient city.

In the last decades of the second century BC, a vicus rose in Fioccaglia (Flumeri), about $8 \mathrm{~km}$ north-east of Aeclanum, immediately to the east of Ufita River. There are no epigraphic sources and it was destroyed at the beginning of the first century BC (Johannowsky, 1990: 269-80). It is likely that the centre is to be linked to the land division promoted by Gracchi (Camodeca, 1997: 265) and is probably the caput viae of a consular road documented by two milestones bearing the inscription consul Aemilius M.f. Lepidus, with the numerals II and XI ICIL IX 6073; $A E$ 1997, 401). Considered the provenance of the milestones from the territory between Fioccaglia and Aequum Tuticum, it is possible that the road, probably the via Aemilia (Camodeca, 1997: 263-70) linked the two centres and then went on towards Daunia (Gangemi, 1987: 119; Johannowsky, 1991: 69 ; Ceraudo, 2015: 232-236). If the inscription of milestones is correct, this would be even more of a confirmation that Romanisation policy was implemented in the territory through strengthening roads and land divisions (fig. 4).

With the establishment of the municipium, governed by IIII viri iure dicundo, Aeclanum is ascribed to the Cornelia tribe. In the territory, archaeological surveys have documented, from the first century BC, new settlements. Frequently among the common kitchen pottery is the presence of fragments of testa and clibani, used for the preparation of savoury and sweet buns and spread in the same period in the Samnite area and inner Campania, demonstrating a socio-economic and alimentary conservatism that lasts until the Early Imperial Age (Federico, 1996: 183). During the first 


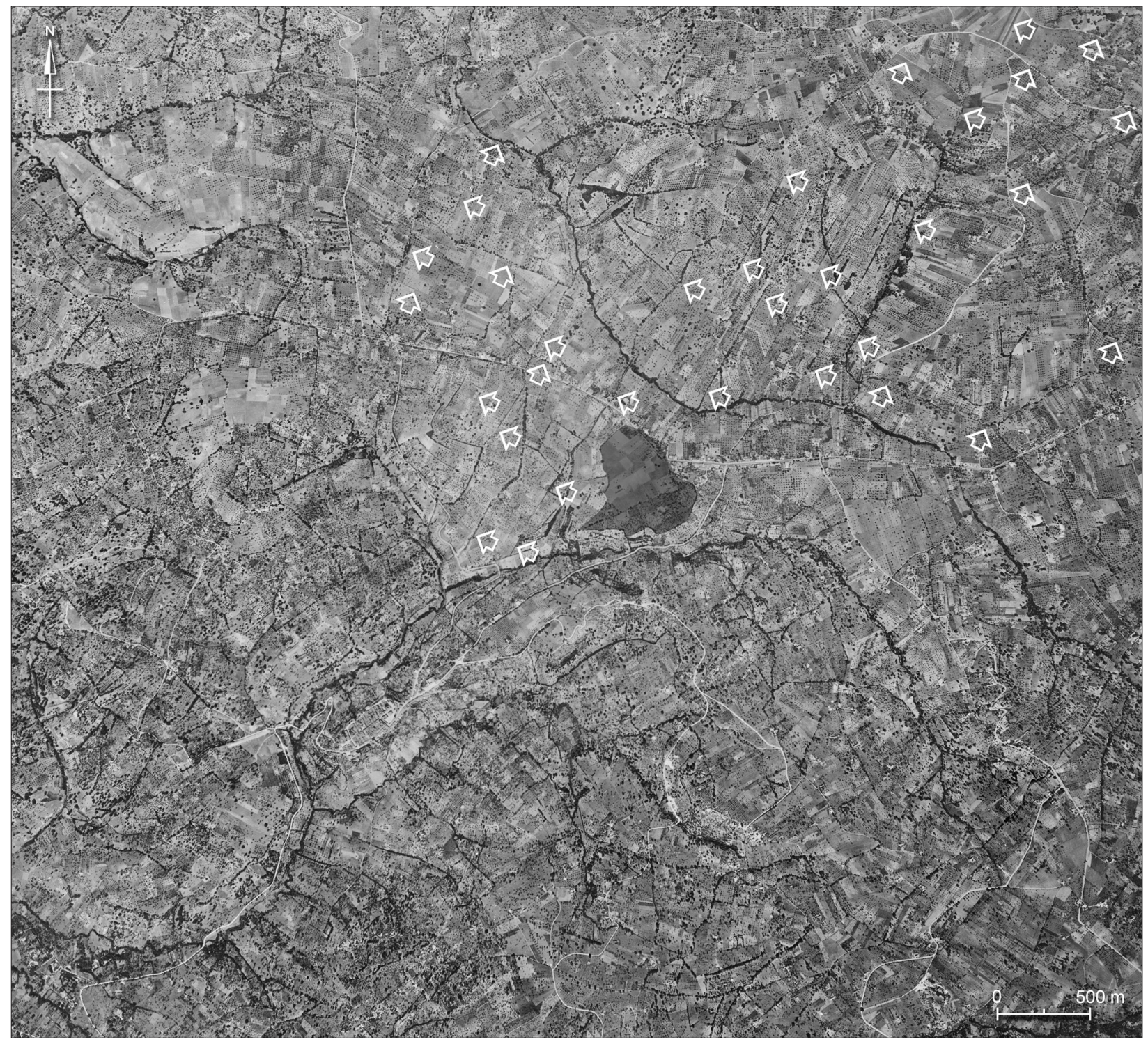

Fig. 4 here: Fig. 4. Central part of investigated area in a detail of historical photograph. Arrows highlight probably ancient limites identified in a small sector of the territory just around the city (IGM 1955, phot. 8882, strip 185).

two centuries of the Empire, the investigated territory is densely populated; some of the settlements previously documented show a continuity of life.

In the years between Hadrian and Antoninus Pius roads were upgraded linking Aeclanum and eastern Apulia with the construction of a via ducente Herdonias or euntibus Apulia. The restora- tion of via Appia only up to Aeclanum and the opening of via Traiana (AD 109) had effectively cut off the long-distance traffic to the city; so the creation of a new road had become necessary. Between the Hadrian and Antonine empires, scholars generally refer to the intervention of land division at Aeclanum remembered in Libri Coloniarum (II, 261, 5-8 L): “ager Aeclanensis [...] lege est assignatus qua et ager Canusinus". The territory of the two cities would be reorganised probably without the arrival of new colonies (Compatangelo-Soussignan, 1999: 171) and affected by two different modules ( $20 \times 24$ actus at Aeclanum, 20 × 20 actus at Canusium: Lib. colon., II, 260, 25-27 L). 
The archaeological record documented during field walking does not allow assigning with certainty the intervention of land division in the years after the founding of the colony, nor the previous time on the formation of the municipium. Furthermore, in the neighbouring territories of ager Aeclanensis there are a lot of documentation consisting of land divisions realised during the Gracchan period (Lib. colon., I, 210, $7 \mathrm{~L}$ and II, 261, 1 L; CIL IX 1024, 1025; Colucci Pescatori, 1991: 89-90; Uggeri 2001; Buonopane, 2012: 326-29; Id. 2013; Isayev, 2013; 19-25; Gallo, 2015; 16-21). We cannot say the same for the territory of Canosa (Grelle, 1993: 41). However, the study conducted on historical maps, historical and recent aerial photographs have allowed the identification, in the course of this work, of a regular land division of the territory of Aeclanum recognisable, for an area of at least 150,000 ha, mainly in the territory to the north and east of the city, where there are the most survivals of possible ancient limites, and also beyond the Ufita River, in the plain up to Carife and close to Fioccaglia.

With the administrative and territorial reform planned by Diocletian, Aeclanum, together with Compsa, is assigned to Apulia (Lib. colon., 210, 3; CIL IX 1115, 1116, 1117, 1127). In the area surrounding the colony, the change of rules does not seem to determine specific changes in the distribution of the archaeological evidence documented during survey; in fact, most of the settlements dated between second and third century AD manifest a continuity of life from the Early Imperial Age and only a few settlements were abandoned. The earthquakes of 346,375 and the Vesuvius eruption of "Pollena" in AD 476 ldocumented in the forum and in extra urban areas by recent excavations: Lo Pilato, 2010: 352) contribute to the slow socio-economic transformation of the city, although Aeclanum in the early fifth century was seat of a bishopric, demonstrating a certain dynamism.

The reconstructed picture for the city corresponds to homogeneous documentation from the territory, where, despite registering a decrease in the presence of rural settlements, most of the existing ones between the second and third cen- tury manifest the tendency of the continuity of life, sometimes even up to the sixth century.

Systematic exploration led to the increase of about $75 \%$ of the number of known archaeological evidence formerly published, as well as a check of the state of preservation of those noted, improving their contextualisation, specifying the topographic location and taking care of the analytical objectivity of previous analyses (fig. 5). These data contribute to enriching the framework of reconstruction of the ancient population in the investigated area.

\section{Acknowledgments}

I am grateful to Prof. Ceraudo for supporting me in all stages of research. I would like to thank the Superintendent Archaeologist Dr. A. Campanelli and the official responsible for the Province of Avellino when I conducted the research, Dr. M. Fariello, for their cooperation.

\section{Reference}

Buonopane A, 2012: Iter Epigraphicum Compsanum, Rend. Pont. Acc. Rom. Arch., 83, 313-37.

Buonopane A, 2013: Un nuovo termine graccano dall'ager di Compsa, Agri Centuriati, 10, 185-202.

Camodeca G, 1997: M. Aemilius Lepidus, cos. 126 a.C., le assegnazioni graccane e la via Aemilia in Hirpinia, Zeitschrift fur papirologie epigraphik, 115, 263-70.

Ceraudo G, 2015: La via Appia (a sud di Beneventol e il sistema stradale in Puglia tra Pirro e Annibale, in La Magna Grecia da Pirro ad Annibale. Atti del Cinquantaduesimo Convegno di studi sulla Magna Grecia (Taranto, 27-30 Settembre 2012): 213-245, Taranto. Colonna G, 1960: s.v. Aeclanum, Enciclopedia dell'Arte Antica, vol. 3, 207-208.

Colucci Pescatori G, 1991: Evidenze archeologiche in Irpinia, La romanisation du Samnium aux $\|^{\text {e }}$ et I $^{\text {er }}$ siècles av. J.-C. Actes du colloque organisé par le Centre Jean Bérard, Naples, 4-5 Novembre 1988: 85-122, Centre J. Bèrard, Naples.

Compatangelo-Soussignan R, 1999: Centuriazione senza coloni? Il caso di Canosa nel quadro della regio Apulia 

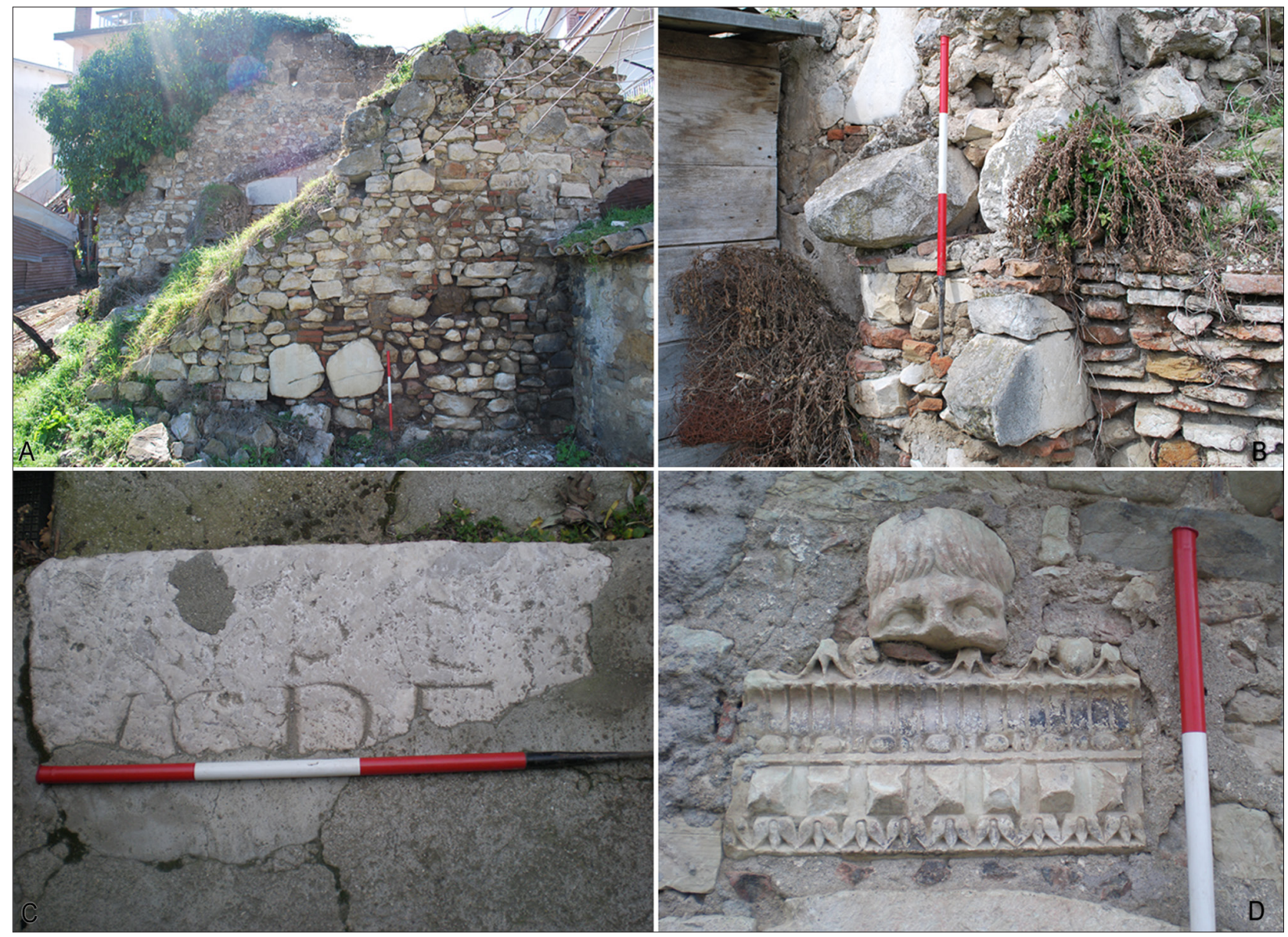

Fig. 5. Ancient elements reused in the territory: A-B, basoli, probably of via Appia, reused in the costruction of old houses, like the numerous fragmentary inscriptions and the architectonic elements (C-D).

et Calabria, in Gravina A (ed.), La Daunia romana: città e territorio dalla romanizzazione all'età imperiale. $17^{\circ}$ Convegno Nazionale sulla Preistoria, Protostoria, Storia della Daunia, San Severo, 6-8 Dicembre 1996: 167-83. Centro Grafico S.r.l., San Severo.

Di Giovanni V, 1996: Aeclanum romana: le evidenze archeologiche, in Colucci Pescatori G, Cuozzo E \& Barra F (ed.), Storia illustrata di Avellino e dell'Irpinia. L'Irpinia Antica: 241-55. Sellino \& Barra Editori, Pratola Serra.

Ditaranto I, 2013: Aerotopografia e fotogrammetria finalizzata per la carta archeologica di Aeclanum, Archeologia Aerea, 7, 53-64.

Federico R, 1996: La ceramica comune dal territorio dei Liguri Baebiani, in Bats M (ed.), Les céramiques communes de Campanie et de Narbonnaise (1. s. av. J.-C.-2. s. ap. J.-C.): la vaisselle de cuisine et de table. Actes des Journées d'étude organisées par le Centre Jean Bérard et la Soprintendenza archeologica per le province di Napoli e Caserta, Naples, 27-28 May 1994: 183-200. Centre J. Bérard, Naples.

Galasso G, 2001: Grottaminarda. Storia, arte, immagini, De Angelis, Avellino.

Gallo A, 2015: L'Hirpinia fra III e I sec.: agro pubblico, assegnatari viritani, giurisdizione delegata, assetto istituzionale, in Quaderni Lupiensi di Storia e Diritto, V, 1-32.

Gangemi G, 1987: Osservazioni sulla rete viaria antica in Irpinia, in L'Irpinia nella società meridionale, Annali del centro Dorso, vol 2, Le immagini: cultura popolare, antichi e nuovi paesaggi: 117-23. Edizioni del Centro Guido Dorso, Avellino.

Grelle F, 1993: Canosa Romana, L’Erma di Bretschneider, Roma. 
Guarini R, 1812: Ricerche sull'antica città di Eclano, Domenico Sangiacomo, Napoli.

Hülsen C, 1894: s. v. Aeclanum, in Pauly-Wissowa, I, coll. 443-444.

Johannowsky W, 1990: L'abitato tardo-ellenistico a Fioccaglia di Flumeri e la romanizzazione dell'Irpinia, in Salvatore M (ed.), Basilicata. L'espansionismo romano nel sud-est d'Italia. II quadro archeologico. Atti del Convegno, Venosa, 2325 Aprile 1987: 269-80. Ed. Osanna, Venosa.

Johannowsky W, 1991: Circello, Casalbore e Flumeri nel quadro della romanizzazione dell'Irpinia, in La romanisation du Samnium aux II et ler siècles av. J.-C. Actes du colloque organisé par le Centre Jean Bérard, Naples, 4-5 Novembre 1988: 57-83. Centre Jean Bérard, Naples.

Isayev E, 2013: Italian Perspectives from Hirpinia in the period of Gracchan land reforms and the social war, in A. Gardner, E. Herring and K. Lomas (eds.), Creating Ethnicities and Identities in the Roman World: 11-34. Institute of Classical Studies, London.

Lo Pilato S, 2010: Organizzazione e destrutturazione dell'insediamento di Aeclanum: considerazioni, in Giuliani R \& Volpe G (ed.), STAIM 2. Paesaggi e insediamenti urbani in Italia meridionale tra tardo antico e alto medioevo, Atti del Secondo Seminario sul Tardoantico e l'Altomedioevo in Italia meridionale, Foggia-Monte Sant'Angelo, 27-28 Maggio 2006: 349-65. Edipuglia, Bari.

Lo Pilato S, 2013: La via Appia tra Ponte Rotto ed Aeclanum, Archeologia Aerea, 7, 44-52.

Mertens J, 1971: Ordona III. Rapports et études, Academia Belgica, Bruxelles/Rome.

Nava ML, 2011: Attività della Soprintendenza per i Beni Archeologici di Salerno, Avellino, Benevento e Caserta in La vigna di Dioniso: vite, vino e culti in Magna Grecia. Atti del Quarantanovesimo Convegno di studi sulla Magna Grecia, Taranto, 2429 settembre 2009: 741-814. Istituto per la storia e l'archeologia della Magna Grecia, Taranto.

Onorato GO, 1960: La ricerca archeologica in Irpinia, Amministrazione Provinciale di Avellino, Avellino.

Ruggiero M, 1888: Degli scavi di antichità nelle province di terraferma dell'antico regno di Napoli dal 1743 al 1876, Tip. Morano, Napoli.
Sgobbo I, 1930: Monumenti epigrafici oschi scoperti ad Aeclanum, in Notizie degli Scavi di Antichità, Atti dell'Accademia Nazionale dei Lincei, 55, 400-11.

Sgobbo I, 1931: La fortificazione romana ad Aeclanum, in AA.VV., Estratto degli Atti del II Congresso Nazionale di Studi Romani: 3-11. Ed. Cremonese, Roma.

Talamo P \& C Ruggini, 2005: Il territorio campano al confine con la Puglia nell'età del Bronzo, in Gravina A (ed.), Atti del $25^{\circ}$ Convegno Nazionale sulla Preistoria, Protostoria, Storia della Daunia, San Severo, 3-5 Dicembre 2004: 171-88. Centro Grafico S.r.l., San Severo.

Uggeri G, 2001, Le divisioni agrarie di età graccana: un bilancio, in S. Alessandrì, F. Grelle (eds.), Dai Gracchi alla fine della Repubblica. Atti del V Convegno di Studi sulla Puglia romana, Mesagne, 9-10 aprile 1999: 31-60. Congedo Editore, Galatina. 
